\title{
EVALUATION OF BONE MINERAL DENSITY USING RADIOGRAPHIC OPTICAL DENSITOMETRY OF PRE AND POSTPUBERTAL BITCHES SUBMITTED TO OVARIOHYSTERECTOMY
}

(Avaliação da densidade mineral óssea por meio da densitometria óptica radiográfica de cadelas pré e pós-púbere submetidas à ovariohisterectomia)

\section{Alfredo F.M. Lima, Stélio P.L. Luna, Sheila Canevese Rahal, Rúbia Tomacheuski, Bruna Martins Silva, Ivan Felismino Charas dos Santos*}

Faculdade de Medicina veterinária e Zootecnia (FMVZ, Botucatu), Universidade Estadual Paulista (UNESP), Botucatu, São Paulo, Brasil

*Corresponding author: ivansantos7@hotmail.com

ABSTRACT - The reduction of gonadal steroid hormone secretion is identified as one of the factors responsible for the decrease in bone mass and, consequently, a decrease in bone mineral density. The study aimed to evaluate the bone mineral density by using radiographic optical densitometry of the distal epiphyseal region of the radius and ulna in prepubertal and post pubertal bitches submitted to ovariohysterectomy (OVH). Thirtyfour female dogs were divided into two groups of 16 animals, according with age of neutering: $\mathrm{G} 1$ - prepubertal bitches submitted to $\mathrm{OVH} ; \mathrm{G} 2$ - postpubertal bitches submitted to $\mathrm{OVH}$. The animals were submitted to the evaluation of bone mineral density at $24 \mathrm{~h}$ before the surgical procedure, 24 and 48 weeks after the surgical procedure. No significant differences in bone mineral density were identified in all groups. Ovariohysterectomy in pre and postpubertal bitches did not induce significant variations in bone mineral density of the distal epiphyseal region of the radius and ulna by using radiographic optical densitometry, during 48 weeks of evaluation.

Key words: gonadectomy; radio; radiography; small animals; ulna.

RESUMO - A redução da secreção do hormônio esteróide gonadal é identificada como um dos fatores responsáveis pela diminuição da massa óssea e consequentemente pela diminuição da densidade mineral óssea. O objetivo do estudo foi avaliar a densidade mineral óssea por meio da densitometria óptica radiográfica da região epifisária distal do rádio e ulna em cadelas pré-púbere e pós-púbere submetidas à ovariohisterectomia $(\mathrm{OVH})$. Trinta e duas cadelas foram divididas em dois grupos de 16 animais, de acordo com a idade submetidas à contracepção: G1 - cadelas pré-púberes submetidas a OVH; G2 - cadelas pós-púberes submetidas a OVH. Os animais foram submetidos à avaliação da densidade mineral óssea 24 horas antes do procedimento cirúrgico, 24 e 48 semanas 
após o procedimento cirúrgico. Foi observado um aumento não significativo na densidade mineral óssea em todos os grupos. A ovariohisterectomia em cadelas pré e pós-púbere não induziram variações significativas na densidade mineral óssea da região epifisária distal do rádio e ulna utilizando densitometria óptica radiográfica, durante 48 semanas de avaliação.

Palavras-chave - gonadectomia; pequenos animais; rádio; radiografia; ulna.

\section{INTRODUCTION}

Bone tissue has several functions that include supporting the soft tissue, protection of vital organs, deposit of calcium and phosphate, and others; and undergoes for continuous remodeling in direct proportion to stress and increasing the thickness when it is constrained to a greater weight load (Notelovitz, 1993). Osteoporosis is characterized by a progressive and generalized decrease in bone mass and bone resistance and is associated with estrogen deficiency (Notelovitz, 1993; Flieger et al., 1998). However, the mechanisms by which the depletion of this hormone induces a decrease in bone mass are not fully understood (Flieger et al., 1998).

Studies showed that estrogenic replacement in Beagles bitches submitted to gonadectomy resulted in the preservation of the cortical mass (Karambolova et al., 1987). However, estrogen replacement in these animals preserved the mass bone (Schmidt et al., 2006). However, another study in female puppies overwent to spay surgery, observed that the bone mineral density was higher in animals submitted to the surgical procedure than those not submitted (Ekici et al., 2005).

Radiographic optical densitometry or photodensitometry is a non-invasive and low-cost radiographic technique with high accuracy and is used to evaluate bone mineral density or bone mass variation (Gallo et al., 1996; Carvalho Filho, 1997; Louzada et al., 1998).

Dogs and cat's overpopulation are complex animal welfare problems in different regions of the world (Garcia et al. 2012). This situation can also affect animal health and welfare, traffic accidents, and attacks on humans (Garcia et al., 2012). Strategies employed by animal shelters and animal control agencies may not apply to all individual dogs and cats (Almeida et al., 2005; Garcia et al., 2012), although spaying and neutering can decrease the overpopulation (Garcia et al., 2012). Neutering has been used in prepubertal dogs and cats with age from six to 14 weeks, however this procedure creates controversies among veterinarians due to slight knowledge about scientific data that can 
justify this practice in younger animals, and beneficial or harmful effects on the anesthetic protocol and the surgical technique (Almeida et al., 2005).

Estrogen is a steroidal hormone associated with the reproductive cycle and relates to bone growth and bone maintenance, electrolyte balance, calcium, and phosphorus retention, direct effect on osteoclasts, inhibiting direct and indirect bone resorption and bone matrix digestion (Notelovitz, 1993). In older animals, bone changes after spaying or neuter are similar to bone changes seen in women after menopause or after gonadectomy (Speroff et al., 1996). In these cases, bone mineral density decreases rapidly due to the absence of estrogens, resulting in deterioration of bone microarchitecture, and an increased risk of bone fractures (Speroff et al., 1996). Cenci et al. (2000) and Takayanagi et al. (2000) performed a study to determine the pathophysiology of bone resorption after ovariectomy in rats, and it was observed that estrogens regulated the function of $T$ cells causing an increase in the production of Tumor Necrosis Factor (TNF), thus increasing osteoclastogenesis.

Few prospective studies have been carried out to determine the consequences of neutering in pre and post-pubertal female dogs (Malluche et al., 1986; Malluche et al., 1988; Johnson et al., 1997). Since there is controversy in the literature regarding the influence of contraceptive surgeries in bone mineral density in different age groups, the present study aimed to evaluate the bone mineral density of the distal epiphyseal region of the radius and ulna in prepubertal and postpubertal bitches submitted to gonadectomy by using radiographic optical densitometry. The hypothesis is that ovariohysterectomy in prepubertal female dogs can induce a decrease in the bone mineral density of the distal epiphyseal region of the radius and ulna during 48 weeks of evaluation.

\section{MATERIAL AND METHODS}

\section{Animals}

Thirty-four clinically healthy pre and postpubertal female dogs, different breeds, were used. The animals were randomly divided in two groups of 16 dogs: G1 prepubertal bitches submitted to $\mathrm{OVH}$; $\mathrm{G} 2$ - post-pubertal bitches submitted to $\mathrm{OVH}$.

Inclusion criteria were prepubertal female dogs aged between three and seven months; and postpubertal bitches - aged from nine to 84 months; no changes during the clinical and orthopedic exam; no alterations in blood cell count, biochemical analysis (alanine aminotransferase, creatinine, total serum protein, and albumin). Exclusion criteria 
were bitches that had undergone a surgical procedure, and that received medication at least one year before the study.

\section{Anesthetic and surgical procedure}

All animals underwent hair clipped of the abdominal region, from the xiphoid cartilage region to the pubic region, following by antisepsis with chlorhexidine (2\%). Preanesthetic medication included acepromazine $(0.2 \%)[0.05 \mathrm{mg} / \mathrm{kg}$, intramuscularly (IM)], xylazine (2\%) (1 mg/kg, IM) and morphine sulfate $(0.5 \mathrm{mg} / \mathrm{kg}, \mathrm{IM})$. The anesthetic induction was performed with ketamine (10\%) (5 mg/kg), and diazepam $(0.25 \mathrm{mg} / \mathrm{kg})$ intravenously (IV) for endotracheal intubation. Anesthetic maintenance was performed with isoflurane and oxygen (100\%).

The animals were placed in the dorsal recumbence and were performed a retroumbilical incision of approximately $2 \mathrm{~cm}$. The abdominal cavity was accessed through an incision in the midline, and the left uterine horn was exteriorized by using an ovariohysterectomy hook, and then, the animals were submitted only to ligation of the ovarian arteriovenous complex with monofilament nylon (2-0) suture wire, and then the ovarian pedicle was incised. Following, the body of the uterus was transfixed with monofilament nylon (0-0) suture wire, and the excision of the ovaries, uterine horns, and uterus were performed. The abdominal walls were closed using a monofilament nylon (20) suture wire using a Sultan suture pattern. The skin was closed using a monofilament nylon (3-0) suture wire using a simple interrupted suture pattern.

\section{Radiographic optical densitometry}

All animals were submitted to the radiographic examination of the distal epiphysis of the right and left radius and ulna in three time-points: 24 hours before the surgical procedure, six and 12 months after the surgical procedure.

The radiographic examination was performed in the craniocaudal projection with a focus-film distance of $100 \mathrm{~cm}$, and $40 \mathrm{~kW}$. The milliamperage varied according to the animal's body mass. The aluminum chassis $(24 \times 30 \mathrm{~cm})$ containing radiographic films were inserted in the chassis holder made of plywood with a thickness of $3 \mathrm{~mm}$, and an aluminum scale (penetrometer) composed of 29 steps was fixed. The first step had a height of $1 \mathrm{~mm}$, with a variation of $1 \mathrm{~mm}$ up to the 29 steps, tolerating a maximum variation of $0.03 \mathrm{~mm}$ in the thickness of each step, with a $5 \times 15 \mathrm{~mm}$ of surface area.

The radiographs were scanned using an HP scanner (Scanjet $4 \mathrm{C}$ ) and stored on a microcomputer. The bone mineral density was determined in millimeters of aluminum 
(mmAl) using a computer program (ATHENA -SAI). Bone mineral density was measured at the distal epiphyses of the radius and ulna of the right and left thoracic limbs. The anesthetic, surgical procedure, and the evaluation of bone mineral density using radiographic optical densitometry were performed by the same person using the blinded method.

The parameters obtained between the groups and the time-points were analyzed statistically using analysis of variance from "SAS" (1996) and the means compared by the Tukey test, with a significance level of $95 \%$.

\section{RESULTS}

The age and body mass of the prepubertal and postpubertal female dogs was 5.4 \pm 1.6 months, and $9.0 \pm 4.9 \mathrm{~kg}( \pm \mathrm{SD}) ;$ and $43.7 \pm 22.6$ months $( \pm \mathrm{SD})$, and $11.2 \pm 6.2$ kg, respectively. The prepubertal bitches' breeds included: crossbreed (86.20\%), Dachshund (4.60\%), Pinscher (4.60\%), and Schnauzer (4.60\%). The postpubertal bitches' breeds included: crossbreed (45.70\%), Cocker spaniel (16.70\%), Poodle (12.50\%), Lhasa Apso (8.30\%), Yorkshire terrier (4.20\%), Blueriller (4.20\%), Pitbull (4.20\%), and Shar-pei (4.20\%) (Figure 1).

The values of the bone mineral density of the distal epiphyseal region of the right radius and ulna of pre and postpubertal bitches submitted to ovariohysterectomy were showed in table 1 . No significant differences in bone mineral density were identified in all groups. 


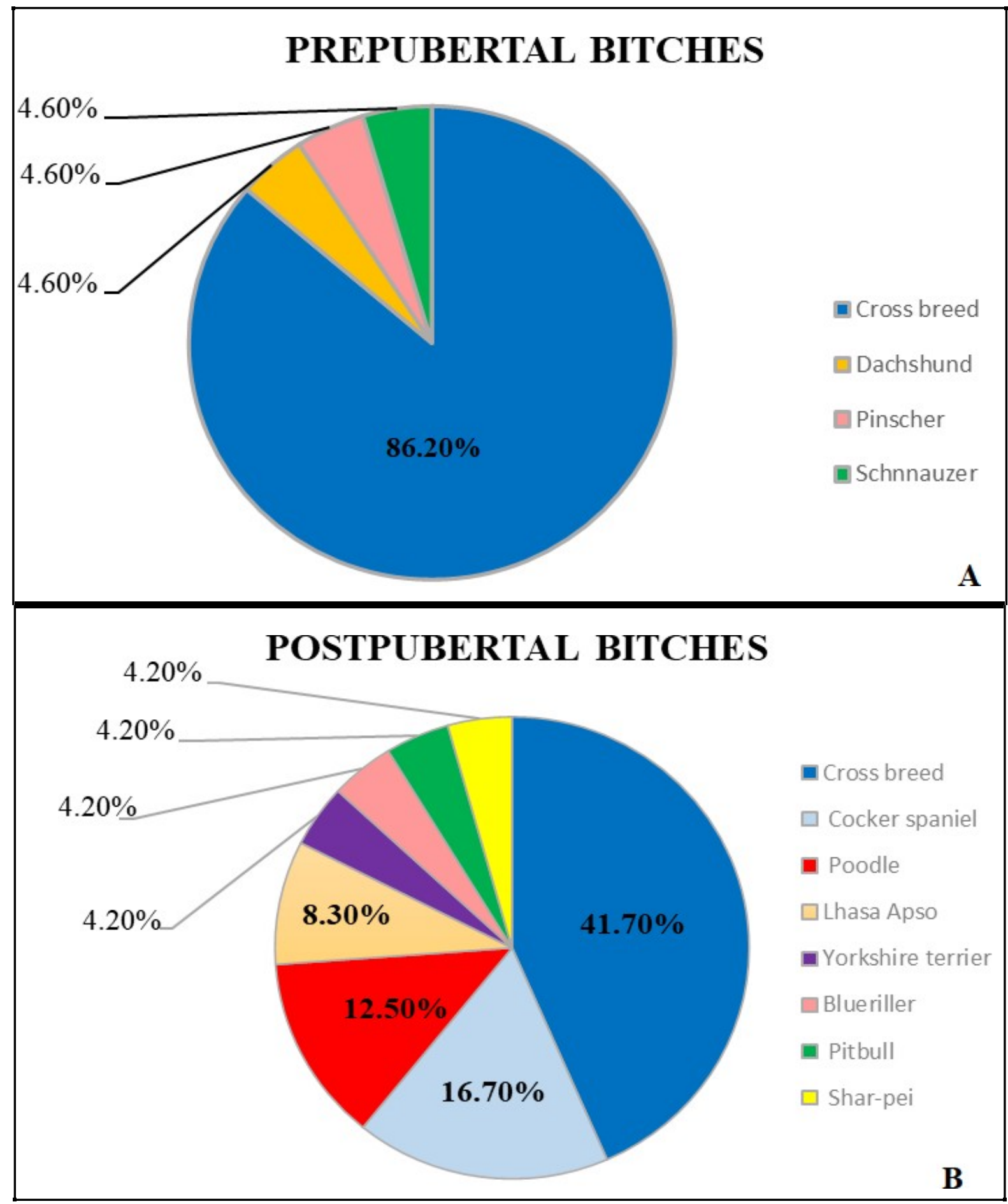

Figure 1 -Pre (A) and postpubertal female dogs. (B) submitted to the bone mineral density of the distal epiphyseal region of the radius and ulna by using radiographic optical densitometry. 
Table 1 - Values of the bone mineral density of the distal epiphyseal region of the right radius and ulna $(R T L)$, and left radius and ulna ( $L T L)$ of pre and postpubertal bitches submitted to ovariohysterectomy at 24 hours before the surgical procedure ( $\left.T_{24 h b e f o r e}\right), 6$ ( $\left.T_{6 m o n t h s}\right)$ and 12 months after the surgical procedure $\left(T_{12 m o n t h s}\right)$.

\begin{tabular}{ccccc}
\hline \multicolumn{2}{c}{ RTL } & \multicolumn{2}{c}{ LTL } \\
\hline Time- & $\begin{array}{c}\text { Prepubertal } \\
\text { points }\end{array}$ & $\begin{array}{c}\text { Postpubertal } \\
\text { Bitches }\end{array}$ & $\begin{array}{c}\text { Prepubertal } \\
\text { bitches }\end{array}$ & $\begin{array}{c}\text { Postpubertal } \\
\text { bitches }\end{array}$ \\
\hline ( $\left._{\text {24hbefore }}\right)$ & $2.25 \pm 0.42^{\mathrm{Aa}}$ & $2.02 \pm 0.44^{\mathrm{Aa}}$ & $2.24 \pm 0.41^{\mathrm{Aa}}$ & $2.01 \pm 0.44^{\mathrm{Aa}}$ \\
( $\left._{\text {6months }}\right)$ & $2.59 \pm 0.47^{\mathrm{Aa}}$ & $2.39 \pm 0.48^{\mathrm{Aa}}$ & $2.60 \pm 0.48^{\mathrm{Aa}}$ & $2.38 \pm 0.48^{\mathrm{Aa}}$ \\
(T $\left._{\text {12months }}\right)$ & $2.68 \pm 0.45^{\mathrm{Aa}}$ & $2.58 \pm 0.47^{\mathrm{Aa}}$ & $2.67 \pm 0.45^{\mathrm{Aa}}$ & $2.57 \pm 0.47^{\mathrm{Aa}}$ \\
\hline
\end{tabular}

Mean \pm SD. $(n=16)$. Means followed by different capital letters on the same line were significantly different by the Tukey test $(p<0.05)$. Means followed by different lower-case letters in the same column were significantly different by the Tukey test $(p<0.05)$

\section{DISCUSSION}

The initial hypothesis of the present study was not reached since there was not observed significant variation concerning the bone mineral density of the distal epiphyseal region of the radius and ulna during 48 weeks of evaluation regardless of the age. Following the neutering, the production of estrogen is ceased, and the deficit of this hormone after ovariectomy or natural menopause results in rapid mass bone loss which increases the probabilities of fractures in women patients (Syed e Khosla, 2005). On the other hand, can affect the remodeling process by prolonging the resorption phase, and shortening the formation phase or increasing bone turnover rate (Riggs et al., 2002).

The effect of gonadectomy in healthy female dogs to assess possible changes in bone mineral density corroborated with the literature (Jeffcoat, 1998). Different from the present study, a study conducted by Rosen et al. (1995) evaluated the radiographic optical densitometry in female rats, and observed a significant difference in bone density in rats submitted to contraceptive surgery. Otherwise, the radiographic optical densitometry was performed in femurs and tibia, differently from the present study.

The evaluation of bone mineral density using radiographic optical densitometry were performed by the same person to avoid interpersonal variability. In this study it was possible to prove the results of different studies concerning radiographic optical densitometry which was easy to perform, low cost and that allows measuring the mineral content of bone using radiographic images, corroborated with the literature (Zentek et 
al., 2004; Zotti et al., 2004; Canali et al., 2011). In present study was used radiographic optical densitometry to accessing bone density since was the method available in our laboratory. On the other hand, energy X-ray absorptiometry (DEXA) is used to evaluate bone structures in human patients (Canali et al., 2011). This method is highly accurate and sensitive to measure bone density, in addition to having a lower radiation dose, and being easy to apply (Canali et al., 2011).

Studies related to the bone mineral density using radiographic optical densitometry in animals have been carried out (Zentek et al., 2004; Zotti et al., 2004; Godoy et al., 2005; Giglio et al., 2006). However, few studies have evaluated the bone mineral density of the distal epiphyseal region of the radius and ulna in pre and postpubertal bitches submitted to gonadectomy.

The bone mineral density of the distal epiphyseal region of the radius and ulna of the pre and postpubertal bitches in the present study showed an increase in both limbs, however without significant variation, similar to the literature (Ekici et al., 2005; Ekici et al., 2007). Different from the present study, a study conducted by Stubs et al. (1996) identified the same effects concerning bone development between bitches submitted to surgical contraception at seven weeks of age and bitches submitted to surgical contraception above 28 weeks of age.

The experimental design of the present study had limitations. The randomization of animals between treatments resulted in groups that were not completely homogeneous concerning the breed. The inherent variability in this type of study may have contributed to the absence of significant differences between pre and postpubertal bitches submitted to neutering.

\section{CONCLUSION}

The gonadectomy in pre and postpubertal bitches do not induce significant variations in bone mineral density of the distal epiphyseal region of the radius and ulna by using radiographic optical densitometry, during 48 weeks of evaluation.

\section{Informative notes}

The present study was performed according to the Animal Ethics Commission of the School of Veterinary Medicine and Animal Science - Botucatu, São Paulo State University (UNESP), São Paulo, Brazil (No 0143/2015). The animals were from Botucatu city and owners informed of all procedures and signed a statement of free consent for the use of animals in the study. 


\section{REFERENCES}

ALMEIDA F.M.; PAIXÃO R. L.; LABARTHE N. V. Overpopulation of domestic urban cats (Felis cattus Linnaeus. 1758) - The need to understand in order to control. Clínica Veterinária, n. 58, p. 44-48, 2005.

CANALI G.D.; TAKAHASHI, C.M.; SÁ MELLO, A. et al. Estudo comparativo da densidade óptica óssea obtida em radiografias panorâmicas e da densitometria óssea em mulheres histerectomizadas e não histerectomizadas. Revista Odonto, v.16, n.2, p. 214-219, 2011.

CARVALHO-FILHO. G. Estudo radiográfico do núcleo secundário de ossificação do calcâneo em população normal e acometida de apófise do calcâneo. Ribeirão Preto. 1997. São Paulo, 90p. Tese (Doutorado)- Faculdade de Medicina. Universidade de São Paulo.

EKICI H.; SONTAS B.H.; TOYDEMIR T.S. et al. Effect of prepubertal ovariohysterectomy on bone mineral density and bone mineral content in puppies. Acta Veterinaria Hungarica, v. 53, n.4, p. 469-78. 2005.

EKICI H.; SONTAS B.H.; TOYDEMIR T.S. et al. The effect of prepubertal ovariohysterectomy on spine 1 mineral density and mineral content in puppies: A preliminary study. Research in Veterinary Science, v. 82, n. 1, p.105-109, 2007.

FLIEGER J.; KARACHALIOS T.; KHALDI L. et al. Mechanical stimulation in the form of vibration prevents postmenopausal bone loss in ovariectomized rats. Calcified Tissue International, v. 63, n. 6, p. 510-4, 1998.

GALLO R.N.; RAHAL S.C.; VULCANO L.C. et al. Avaliação da densidade óssea em gatos em crescimento submetidos a dois tipos de ração. In: XV CONGRESSO PANAMERICANO DE CIÊNCIAS VETERINÁRIAS. Campo Grande. Anais Campo

Grande. MS. 1996.

GARCIA R.C.M.; CALDERÓN N.; FERREIRA F. Consolidação de diretrizes internacionais de manejo de populações caninas em áreas urbanas e proposta de indicadores para seu gerenciamento. Revista Panamericana Salude Publica, v.32, n. 2, p. 140-144, 2012.

GIGLIO F.R.; BALIEIRO J.C.C.; STERMAN F. A. et al. Estudo longitudinal da densidade mineral óssea em cães jovens da raça Golden Retriever: Correlações com idade e peso corpóreo. Brazilian Journal of Veterinary Research and Animal Science, v. 43, n. 5, p. 681-687, 2006.

GODOY C.L.D.; VULCANO L.C.; SANTOS F.A.M. et al. Normal values of bone mineral density of the Accessory carpus bone in Brasileiro de hipismo $(\mathrm{BH})$ horse Breed using optical densitometry in radiographic image. Ciência Rural. Santa Maria, v. 35 n. 3, p. 607-610, 2005. 
JOHNSON R. B.; GILBERT J. A.; COOPER R. C. et al. Alveolar bone loss year following ovariectomy in sheep. Journal of Periodontology, v. 68, n. 9, p. 864- 871, 1997.

KARAMBOLOVA K.K.; SNOW G.R.; ANDERSON C. Effects of continuous 17 $\beta$ - estradiol administration on the periosteal and corticoendosteal envelope activity in spayed beagles.

Calcified Tissue International, v.40, p.12-15, 1987.

LOUZADA M.J.Q.; PELÁ C.A.; BELANGERO W.D. et al. Avaliações de densidade óssea em imagens radiográficas: estudo em peças ósseas de cães. Revista Brasileira de Engenharia - Caderno de Engenharia Biomédica. v.14. n.1, p. 47- 64, 1998.

MALLUCHE H.H.; FAUGERE M.C.; RUSH M. Osteoblastic insufficiency is responsible for maintenance of osteopenia after loss of ovarian function in experimental Beagle dogs. Endocrinology, v. 119, p. 2643, 1986.

MALLUCHE H.H.; FAUGERE M.C.; RUSH M. et al. 1,25-Dihidroxyvitamin D3 corrects bone loss but suppresses bone remodeling in ovariohysterectomized Beagle dogs. Endocrinology, v.122, p.1998-2006, 1988.

NOTELOVITZ M. Osteoporosis: screening. prevention and management. Fertilitlity and Sterilility, v. 59, p. 707-725, 1993.

RIGGS B.L.; KHOSLA S.; MELTON L.J. Sex steroids and the construction and conservation of the adult skeleton. Endocrine Reviews, v. 23, n.3, p. 279-302. 2002.

ROSEN H.N.; TOLLIN S.; BALENA R. et al. Differentiating between orchiectomized rats and controls using measurements of trabecular bone density a comparison among DXA: histomorphometry and peripheral quantitative computerized tomography. Calcified Tissue International, v. 57, p. 35-39, 1995.

SCHMIDT C.; FRANCO S.R.V.S.; VULCANO L.C. et al. Densidade mineral óssea em cadelas submetidas à ovariohisterectomia com e sem reposição estrogênica oral. Arquivo Brasileiro de Medicina Veterinária e Zootecnia, v.58, n.4, p. 506-510, 2006.

SPEROFF L.; ROWAN J.; SYMONS J. et al. The comparative effect on bone density endometrium and lipids of continuous hormones as replacement therapy. Obstetrical \& Gynecological Survey, v.6, p. 1397-1403, 1996.

SYED F.; KHOSLA S. Mechanisms of sex steroid effects on bone. Biochemical and Biophysical Research Communications, v. 328, p. 688-696. 2005.

ZENTEK J.; LIESENGANG A.; MAYRHOFER E. et al. Comparative assessment of bone mineral measurements obtained by use of dual-energy x-ray absorptiometry peripheral quantitative computed tomography and chemical-physical analysis in femurs of juvenile and adult dogs. American Journal of Veterinary Research, v. 65, p.891-900, 2004. 
ZOTTI A.; ISOLA M.; STURARO E. et al. Vertebral mineral density measured by dual-energy $X$-ray absorptiometry (DEXA) in a group of healthy Italian boxer dogs. Journal of Veterinary Medicine, v.51a, p. 254-258, 2004. 